\title{
Planktonic Cyanobacteria of the tropical karstic lake Lagartos from the Yucatan Peninsula, Mexico
}

\author{
Francisco Valadez*1,3, Gabriela Rosiles-González ${ }^{1}$, Antonio Almazán-Becerril ${ }^{1}$ \& \\ Martin Merino-Ibarra ${ }^{2}$
}

1. Unidad de Ciencias del Agua, Centro de Investigación Científica de Yucatán A.C., Calle 8, No. 39, L. 1, Mz. 29, Sm 64, C.P. 77524, Cancún, Quintana Roo, México; fvc_2001@yahoo.com, gabriela.rosiles@cicy.mx, almazan@cicy.mx

2. Unidad Académica de Ecología y Biodiversidad Acuática, Instituto de Ciencias del Mar y Limnología, Universidad Nacional Autónoma de México, Circuito Exterior s/n, Cd. Universitaria, Coyoacán 04510 D.F., México; mmerino@cmarl.unam.mx

3. Present address: Laboratorio de Humedales, CICART, División Académica de Ciencias Biológicas, Universidad Juárez Autónoma de Tabasco, 0.5 km carretera Villahermosa-Cárdenas, C.P. 86039, Villahermosa, Tabasco, México.

* Correspondence author

\author{
Received 18-VI-2012. Corrected 03-IX-2012. Accepted 05-X-2012.
}

\begin{abstract}
Las cianobacterias planctónicas del lago tropical cárstico Lagartos de la Península de Yucatán, México. The tropical karstic lakes on the Mexican Caribbean Sea coast are numerous. However, there is an enormous gap of knowledge about their limnological conditions and micro-algae communities. In the present study, surface water samples were collected monthly from November 2007 to September 2008 to provide taxonomical composition and biovolume of planktonic cyanobacteria of the lake Lagartos from State of Quintana Roo, Mexico. Water temperature, $\mathrm{pH}$, conductivity, salinity, soluble reactive phosphorus (SRP), dissolved inorganic nitrogen (DIN), and soluble reactive silica (SRSi) levels were also analyzed. A total of 22 species were identified. Chroococcales and Oscillatoriales dominated the phytoplankton assemblages during the study period. Chroococcus pulcherrimus, Coelosphaerium confertum, Cyanodyction iac, Phormidium pachydermaticum and Planktolyngbya contorta were recorded for the first time in Mexico. A surplus of DIN (mean value of $42.7 \mu \mathrm{M}$ ) and low concentrations of SRP (mean value of $1.0 \mu \mathrm{M}$ ) promoted the enhanced growth and bloom formation of cyanobacteria. The mean biovolume was $3.22 \times 10^{8} \mu \mathrm{m}^{3} / \mathrm{mL}$, and two biovolume peaks were observed; the first was dominated by Microcystis panniformis in November $2007\left(7.40 \times 10^{8} \mu \mathrm{m}^{3} / \mathrm{mL}\right)$, and the second was dominated by Oscillatoria princeps in April $2008\left(6.55 \times 10^{8} \mu \mathrm{m}^{3} / \mathrm{mL}\right)$. Water quality data, nitrates enrichment, and trophic state based on biovolume, indicated that Lagartos is a hyposaline, secondarily phosphorus-limited, and eutrophic lake, where the cyanobacteria flora was composed mainly by non-heterocystous groups. Rev. Biol. Trop. 61 (2): 971-979. Epub 2013 June 01.
\end{abstract}

Key words: cyanobacteria, bloom, water quality, nutrients, eutrophic, Quintana Roo.

The hydrogeology of the Yucatan Peninsula, in the Southeastern Mexico, is controlled by a karst system, where secondary porosity and high permeability promotes the formation of large caverns, dissolution cavities, sinkholes and channels conducting substantial quantities of water (Reddell 1981). Lakes can be formed when the superficial cavities in the limestone are filled permanently by the water table. These aquatic systems are called dissolution lakes according to Hutchinson (1957), or coastal lakes (Cole 1979). The karstic lakes occur mainly in the tropical and subtropical carbonate platforms like the Caribbean Sea (Mylroie \& Carew 1995), Florida (Florea \& Vacher 2006), in countries bordering the Mediterranean Sea (Lopez et al. 2009, Casamayor et al. 2012) and South China Sea (Cerrano et al. 2006). When karstic water bodies are located near the coast, they tend to be smaller and shallower. These features make them highly vulnerable to significant inputs of organic matter from their surroundings, especially in densely populated and agricultural areas (McComb \& Davis 
1993, Smith 2003). If there is a not lightlimited condition, the nutrient enrichment will drive an increase of phytoplankton biomass (Reynolds 1984, McComb \& Davis 1993). Thus, phytoplankton communities could constitute an important element for interpreting the functioning of lakes (Reynolds et al. 2002), but their successful application requires a precise understanding of species identities and limnological preferences.

Despite the presence of nearly 80 karstic aquatic bodies on the coast of Mexican Caribbean Sea (CONAGUA 2002), there is an enormous gap of knowledge about the limnology of these aquatic systems and their micro-algae communities. High nutrient input can cause eutrophication and a remarkable diminution in the water quality with the concomitant loss of phytoplankton biodiversity, much of it unknown until now. Recent studies particularly focused on taxonomic composition of phytoplankton communities of sinkholes and anchialine caves, have highlighted the importance of inland water bodies to harboring a large freshwater micro-algae diversity (López-Adrian \& Herrera-Silveira 1994,
Sánchez et al. 2002, Schmitter-Soto et al. 2002, Torres-Talamante et al. 2011). However, there are not any references on planktonic or benthonic micro-algae communities structure and seasonal succession in coastal lakes from the Mexican Caribbean Sea shoreline. Therefore, the aim of this study was to provide the first report on the flora of planktonic cyanobacteria, their seasonal fluctuations in terms of biovolume in relation to climatic variability in the coastal karstic lake Lagartos from Quintana Roo, México.

\section{MATERIALS AND METHODS}

Study area: Lake Lagartos (Fig. 1) is located at $5 \mathrm{~m}$ above sea level on the Riviera Maya, at $90 \mathrm{~km}$ South of Cancun, Quintana Roo, Mexico $\left(20^{\circ} 24^{\prime} 02^{\prime \prime} \mathrm{N}-87^{\circ} 18^{\prime} 43^{\prime \prime} \mathrm{W}\right)$. It is a small ( $4850 \mathrm{~m}^{2}$ in surface area) and shallow (maximal depth $3 \mathrm{~m}$; average depth $1.7 \mathrm{~m}$ ) aquatic system, located at $450 \mathrm{~m}$ from the Caribbean Sea shoreline. There is no surface inflow or outflow, which makes us suppose that the water level is maintained only by groundwater input. The bottom of the lake is covered by

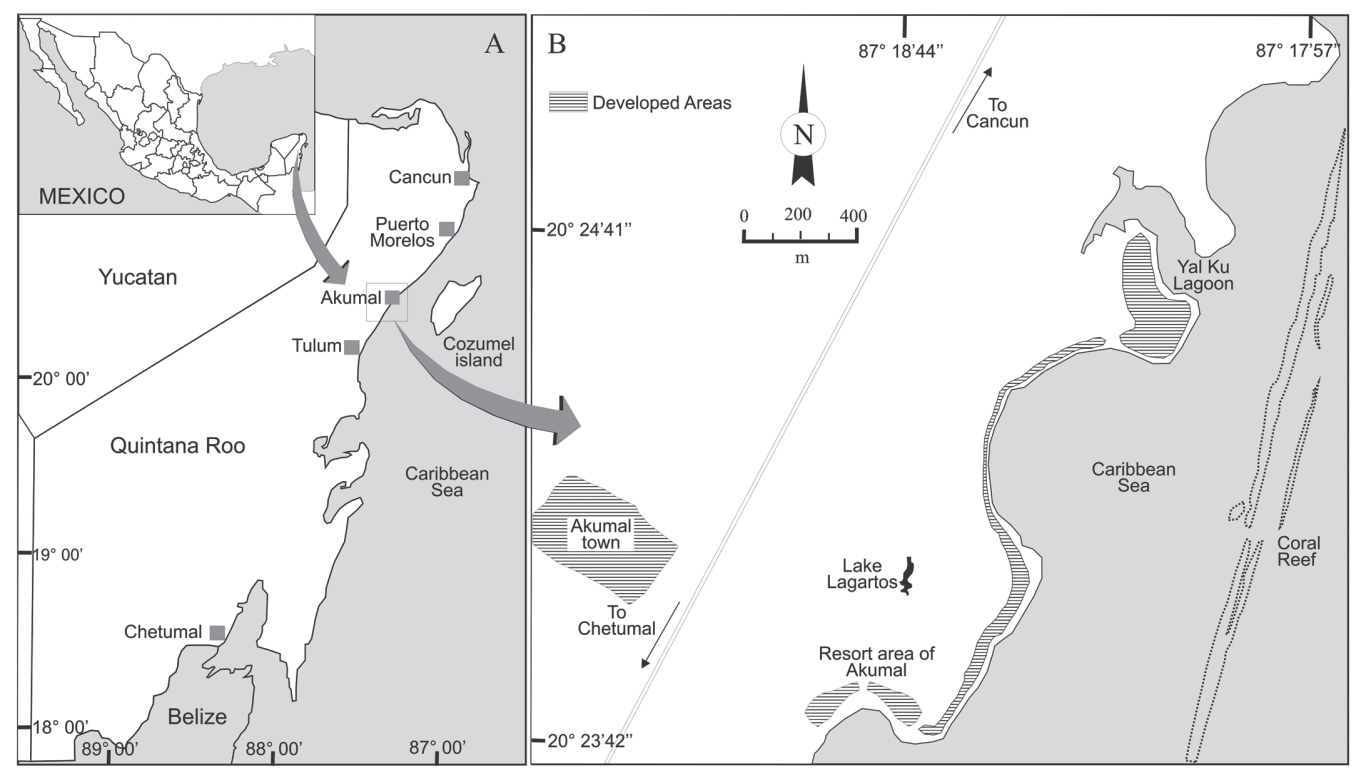

Fig. 1. (A) Study area, the Yucatan Peninsula and the state of Quintana Roo, Mexico; (B) Location of Lake Lagartos and the developed coastline of Akumal. 
submerged macro-algae, mainly Cladophora glomerata (Linnaeus) Kützing 1843 and its shores are surrounded by a belt of mangrove (Rhizophora mangle Linnaeus 1753, Laguncularia racemosa (Linnaeus) C. F. Gaertn 1807, and Conocarpus erectus Linnaeus I753). The climate is characterized by three seasons. The cold fronts season occurs from November to February; this season has mean and maximum rainfall values of 72 and $92 \mathrm{~mm}$, respective. The dry season, occurs from March to May with a mean rainfall of $63 \mathrm{~mm}$ and maximum of $96 \mathrm{~mm}$. The rainy season is from June to October and it is characterized by the higher values of rainfall with a mean of $173 \mathrm{~mm}$ and maximum of $222 \mathrm{~mm}$. The dominant winds (mean velocity of $10 \mathrm{~km} / \mathrm{h}$ ) caused complete mixing of the water column (SMN 2010). Numerous local residential districts, resorts and vacation homes that surround the lake, have caused pollution that has affected the water quality of the lake (Mutchler et al. 2007).

Sampling and analyses: Lake Lagartos was sampled monthly from November 2007 to September 2008, with exception of December 2007. Water temperature, $\mathrm{pH}$, conductivity and salinity were measured in situ with a multiparameter probe (Hydro lab ${ }^{\circledR}$ DS5). Water samples for chemical analyses were filtered through Whatman GF/F filters $(0.45 \mu \mathrm{m}$ pore size $)$, poured into polyethylene bottles and preserved immediately after collection. Soluble reactive phosphorous (SRP), nitrite $\left(\mathrm{NO}_{2}^{-}\right)$, nitrate $\left(\mathrm{NO}_{3}^{-}\right)$, ammonia $\left(\mathrm{NH}_{4}^{+}\right)$and soluble reactive silica (SRSi), were analyzed with a Skalar San Plus segment flow autoanalyzer, according to standard methods adapted by Grasshoff et al. (1983). Dissolved inorganic nitrogen (DIN) was considered as the sum of $\mathrm{NH}_{4}^{+}, \mathrm{NO}_{2}{ }^{-}$and $\mathrm{NO}_{3}{ }^{-}$.

Surface samples for planktonic cyanobacteria identification and counting were collected in the central part of the lake with a Van Dorn (2L) water sampler bottle. The samples were placed in polyethylene bottles of $250 \mathrm{~mL}$ and fixed with a Lugol's acidified solution. Taxonomic identification was done by light microscopic observation (Zeiss PrimoStar) of living and preserved samples. Specialized taxonomic monographs about cyanobacteria (Anagnostidis \& Komárek 1985, 1988, Komárek \& Anagnostidis 1998, 1999) were supplemented with recently published original literature for species identification. Algal numbers were counted with an inverted microscope Zeiss Axiovert 40 CFL at X400 according Utermöhl (1958). At least 30 individual cells of each species were measured and geometric shapes were used to determine biovolume, which is given in $\mu \mathrm{m}^{3} /$ $\mathrm{mL}$ (Willén 1976, Rott 1981). At the end of this investigation, all samples were fixed with a $3 \%$ formaldehyde solution and they were deposited in the Water Sciences Unit-Center for Scientific Research of Yucatan, Micro-algae Collection (CM-CICY).

\section{RESULTS}

Abiotic variables: The seasonal variation in physico-chemical parameters and soluble nutrients are shown in table 1 . Air temperature values varied from 24 to $30^{\circ} \mathrm{C}$, water temperature varied from 26 to $30^{\circ} \mathrm{C}$, the electrical conductivity recorded values were between 13 and $18 \mathrm{mS} / \mathrm{cm}$, the salinity ranged from 8 to $10 \mathrm{psu}$, while $\mathrm{pH}$ was mostly neutral and ranged between 7 and 8 .

The concentrations of nutrients were high. Soluble reactive silica varied from 31.1 to $151.5 \mu \mathrm{M}$, with a mean of $62.7 \mu \mathrm{M}$. The high concentrations of SRSi reflect the huge influence of the aquifer in the lake, mainly during the cold fronts and rainy seasons. Concentrations of DIN varied between 11.3 and $105.1 \mu \mathrm{M}$, with a mean of $42.7 \mu \mathrm{M}$. Nitrates were the dominant nitrogen type from January to April and September 2008, whereas $\mathrm{NH}_{4}^{+}$was the dominant nitrogen type from May to August 2008. The mean $\mathrm{NO}_{2}$ concentration was $0.7 \mu \mathrm{M}$ and its highest concentrations were measured in January and February 2008. Concentrations of SRP varied between 0.2 and $3.8 \mu \mathrm{M}$, with a mean of $1.0 \mu \mathrm{M}$.

Phytoplankton flora and seasonal fluctuations in planktonic cyanobacteria: The 
TABLE 1

Seasonal variation in physico-chemical parameters and soluble nutrients in lake Lagartos, México

\begin{tabular}{lccccccccccc}
\multicolumn{1}{c}{ Season } & \multicolumn{3}{c}{ Cold fronts } & \multicolumn{1}{c}{ Dry } & \multicolumn{5}{c}{ Rainy } \\
& Nov & Jan & Feb & Mar & Apr & May & Jun & Jul & Aug & Sep & Mean \\
Rainfall $(\mathrm{mm})$ [total annual 1 098] & 62.6 & 62.0 & 92.1 & 46.1 & 47.4 & 96.0 & 189.4 & 129.6 & 150.3 & 222.5 & 109.8 \\
Air temperature $\left({ }^{\circ} \mathrm{C}\right)$ & 24.2 & 26.1 & 26.0 & 27.2 & 29.1 & 28.2 & 28.1 & 29.7 & 29.1 & 26.5 & 27.4 \\
Water temperature $\left({ }^{\circ} \mathrm{C}\right)$ & 26.3 & 26.2 & 25.5 & 25.9 & 26.1 & 28.9 & 28.7 & 28.4 & 29.9 & 27.8 & 27.4 \\
Electrical conductivity $(\mathrm{mS} / \mathrm{cm})$ & 16.4 & 17.6 & 15.1 & 16.4 & 14.1 & 14.1 & 13.3 & 13.5 & 15.0 & 15.7 & 15.1 \\
Salinity $(\mathrm{psu})$ & 9.6 & 10.4 & 8.8 & 9.6 & 8.2 & 8.1 & 7.6 & 7.8 & 8.7 & 9.2 & 8.8 \\
pH & 7.2 & 7.2 & 7.4 & 7.3 & 6.9 & 7.5 & 7.7 & 7.4 & 7.3 & 7.0 & 7.3 \\
SRSi $(\mu \mathrm{M})$ & 64.9 & 100.4 & 151.5 & 49.7 & 60.5 & 17.9 & 115.6 & 31.1 & 39.6 & 40.6 & 67.2 \\
Nitrates $(\mu \mathrm{M})$ & 8.0 & 43.5 & 59.4 & 102.5 & 33.8 & 14.2 & 2.6 & 9.8 & 2.7 & 38.9 & 31.5 \\
Nitrites $(\mu \mathrm{M})$ & 0.4 & 1.1 & 2.3 & 0.4 & 0.5 & 0.4 & 0.1 & 0.5 & 0.1 & 0.8 & 0.7 \\
Ammonia $(\mu \mathrm{M})$ & 2.8 & 4.9 & 3.8 & 2.2 & 2.5 & 20.1 & 21.4 & 15.3 & 29.1 & 2.8 & 10.5 \\
SRP $(\mu \mathrm{M})$ & 0.5 & 2.6 & 3.8 & 0.4 & 0.5 & 0.3 & 0.6 & 0.3 & 0.2 & 0.3 & 1.0 \\
DIN $(\mu \mathrm{M})$ & 11.3 & 49.4 & 65.6 & 105.1 & 36.7 & 34.7 & 24.1 & 25.6 & 31.9 & 42.5 & 42.7 \\
DIN:SRP & 23 & 19 & 17 & 263 & 73 & 116 & 40 & 85 & 159 & 142 & 94 \\
\hline
\end{tabular}

phytoplankton was represented by 63 taxa belonging to six Divisions. The Bacillariophyta contributed with the highest number of species (28) followed by Cyanobacteria=Cyanoprokaryota (22), Dinophyta (six), Chlorophyta (three), Euglenophyta (two) and Cryptophyta (two). However, Cyanobacteria were the group with the highest contribution to total phytoplankton biovolume (between 96-99\%) during the period of study.

The Cyanobacteria species list and species richness observed in Lagartos are given in table 2. Chroococcales was the order with the highest number of species (11) followed by Oscillatoriales (nine) and Nostocales (two). Chroococcus pulcherrimus, Coelosphaerium confertum, Cyanodyction iac, Phormidium pachydermaticum and Planktolyngbya contorta were recorded for the first time in Mexico. Species richness was relatively low during the whole study (mean of 19) and the lowest value was recorded on February. The most frequent species were Chroococcus minor, C. minutus, C. turgidus, Cyanodyction iac, Microcystis panniformis, Geitlerinema splendidum and Planktolyngbya contorta.

The mean cyanobacteria biovolume value was $3.22 \times 10^{8} \mu \mathrm{m}^{3} / \mathrm{mL}$ whereas the lowest biovolume values were recorded from June to September (Fig. 2A). Two biovolume peaks occurred, the first in November 2007 $\left(7.39 \times 10^{8} \mu \mathrm{m}^{3} / \mathrm{mL}\right)$ and the second in April $2008\left(6.55 \times 10^{8} \mu \mathrm{m}^{3} / \mathrm{mL}\right)$. Chroococcales presented the highest contributions to total biovolume from November to February and from May to September, and Oscillatoriales from March to April. Nostocales was not abundant throughout the whole study (Fig. 2B). Monthly variation in relative abundance of selected species is illustrated in figures 2C-D. The dominant species were $M$. panniformis and Oscillatoria princeps, which accounted for $36 \%$ and $26 \%$ of the mean total biovolume, respectively, throughout the survey. Both species developed blooms, $M$. panniformis in November 2007 (Fig. 2A and C) and O. princeps in April 2008 (Fig. 2A and D). Both blooms constituted the first records for the State of Quintana Roo, México.

\section{DISCUSSION}

Lagartos is a small shallow water body but it has importance as a typical example of a coastal karstic aquatic system in Southeastern Mexico. Water temperature of the lake followed air temperature rather closely, the circulation pattern was continuum warm polymictic, and 
TABLE 2

Species and richness observed in lake Lagartos, México

\section{Season}

\section{Chroococcales}

Chroococcus minor (Kützing) Nägeli 1849

Chroococcus minutus (Kützing) Nägeli 1849

Chroococcus pulcherrimus Welch 1965

Chroococcus turgidus (Kützing) Nägeli 1849

Coelosphaerium confertum West et G. S. West 1869

Cyanodyction iac Cronberg et Komárek 1994

Gomphosphaeria semen-vitis Komárek 1989

Johannesbaptistia pellucida (Dickie) Taylor et Drouet 1938

Merismopedia punctata Meyen 1939

Microcystis panniformis Komárek,

Komárková-Legnerová, Sant'Ánna, Azevedo et Senna 2002

Synechococcus nidulans (Pringsheim) Komárek in Bourrelly 1970

\section{Oscillatoriales}

Geitlerinema splendidum (Greville ex Gomont) Anagnostidis 1989

Lyngbya hieronymusii Lemmermann 1905

Oscillatoria princeps Vaucher ex Gomont 1892

Phormidium nigro-viride (Thwaites ex Gomont)

Anagnostidis et Komárek 1988

Phormidium pachydermaticum Frémy 1930

Planktolyngbya contorta (Lemmermann)

Anagnostidis et Komárek 1988

Planktothrix agardhii (Gomont) Anagnostidis et Komárek 1988

Porphyrosiphon martensianus (Menenghini ex Gomont)

Anagnostidis et Komárek 1988

Spirulina labyrinthiformis Kützing ex Gomont 1892

\section{Nostocales}

Anabaena sp.

Cylindrospermum sp.

Richness

\section{Cold fronts \\ Nov Jan Feb Mar Apr May Jun Jul Aug Sep}

$+\quad+\quad+\quad+\quad+\quad+\quad+\quad+$

$+\quad+\quad+\quad+\quad+\quad+\quad+$

$+\quad+\quad+\quad+\quad+\quad+\quad+\quad+$

$+\quad+\quad+\quad+\quad+\quad+\quad+$

$+\quad+\quad+\quad+\quad+\quad+\quad+\quad+$

$+\quad+\quad+\quad+\quad+\quad+\quad+\quad+$

$+\quad+\quad+\quad+\quad+\quad+\quad+\quad+\quad+$

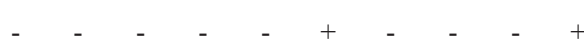

$+\quad+\quad+\quad+\quad+\quad+\quad+\quad+$

$+++++++++$ no thermal stratification was recorded. The lake was classified as hyposaline according to Beadle (1959), with a mean salinity of 8.8psu. The mean depth was low and its bottom could be seen throughout the study. The clear water in this karstic water body can be attributed to dense macro-algae growth: $C$. glomerata and Chara sp., which serve like nutrients sink and as a factor to reduce sediment resuspension (Moss 1990, Scheffer 1998), despite to be a water body frequently mixed because of the dominant winds from the region. On the other hand, the nutrient concentrations were from one to two orders of magnitude higher than other water bodies of the State of Quintana Roo (Alcocer et al. 1999, Schmitter-Soto et al. 2002, Torres-Talamante et al. 2011), and a remarkably high DIN:SRP ratio (mean value 94) suggests a permanent P-limitation in Lagartos according to Danielidis et al. (1996). Although limitation by phosphorus is usual in eutrophic water bodies, the seasonal patterns in Lagartos were more similar to secondary phosphorus limitation like in eutrophic lakes with excessive nitrogen input (Reynolds 1984). Consistent with our findings, Mutchler et al. (2007) attributed the nitrogen enrichment in Lagartos to excessive anthropogenic inputs, 
A

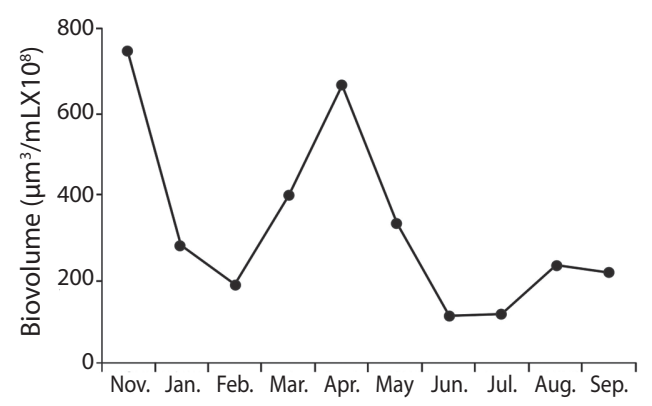

B

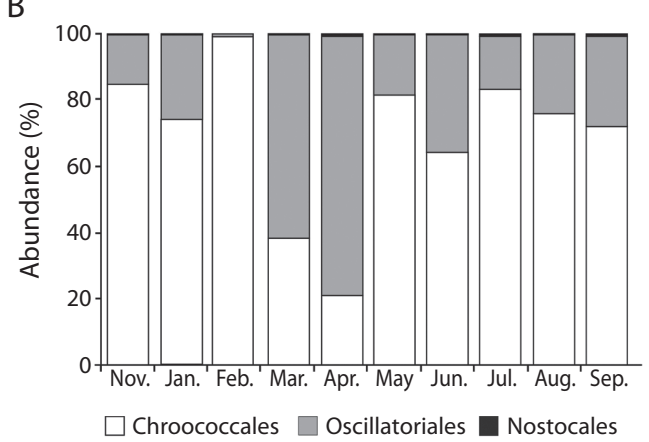

C

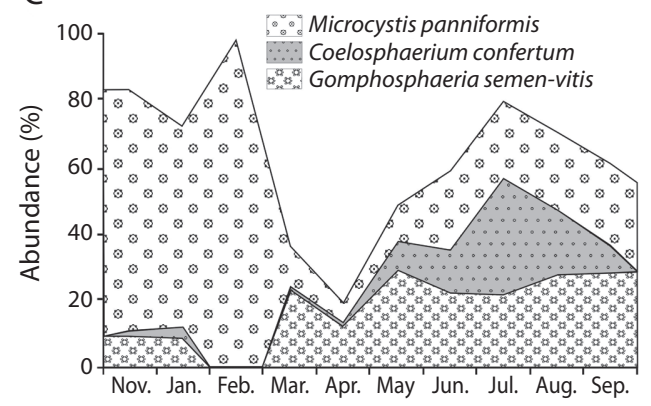

D

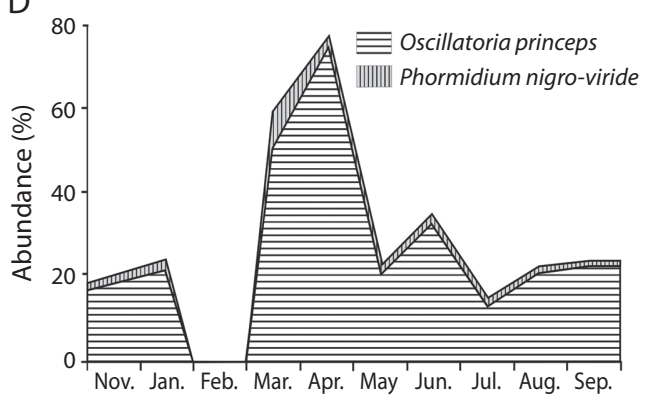

Fig. 2. Monthly variation of: (A) Total biovolume; (B) Relative abundance of main cyanobacteria groups; (C) Relative abundance of major Chroococcales species; (D) Relative abundance of major Oscillatoriales species.

mainly as $\mathrm{NO}_{3}^{-}$, into the groundwater from waste and sewage loading.

The composition of phytoplankton species in Lagartos reveals an accelerated process of eutrophication, with a predominance of non-heterocystous cyanobacteria. Despite their physico-chemical stability and no clear relation between nutrient concentrations and cyanobacteria biovolume values, the lake exhibited interesting differences in their cyanobacteria communities. The biovolume peak dominated by $M$. panniformis, was observed during the early cold fronts season, with a DIN:SRP=23. The dominance of Microcystis species in lakes with high nutrient concentrations may reflect their greater affinity to $\mathrm{P}$ and $\mathrm{N}$ (Jensen et al. 1994, Galat et al. 1981). Consistent with these observations, $M$. panniformis might deplete N and $\mathrm{P}$ concentrations from water column during its excessive growth in Lagartos. Microcystis panniformis blooms could be a potential risk for human health in the study region, since this species has been characterized as a hepatotoxic peptides (microcystins) producer, which cause liver damage (Codd et al. 1999, Almeida et al. 2006, Carvalho et al. 2007, Vasconcelos et al. 2010).

After the Microcystis peak, a decrease in total biovolume and an increase in $\mathrm{NO}_{3}^{-}$ and SRP concentrations were observed from January to March. The increase of $\mathrm{NO}_{3}{ }^{-}$and SRP were attributed to groundwater input during the rainy months of the cold fronts season, and to recycling of organic detritus. On the other hand, Xie et al. (2003) suggested that Microcystis blooms also can induce massive release of both total P (TP) and SRP from the sediment and enhance internal loading, leading to a positive feedback loop. Under this scenery, DIN:SRP ratios between 17-19, with a maximum of 263 in March, favored an excessive growth of C. glomerata (field observations), and its success might limit the growth of planktonic cyanobacteria. 
After the C. glomerata bloom, a peak of $O$. princeps arose in April 2008 under high $\mathrm{NO}_{3}{ }^{-}$ concentrations, low SRP concentrations and $\mathrm{DIN}: \mathrm{SRP}=73$. Oscillatoria princeps has been observed in tropical and temperate shallow water bodies with $\mathrm{P}$ deficiency and high $\mathrm{NO}_{3}{ }^{-}$ concentrations (McCormick et al. 1998, Lu et al. 2006, Tiwari \& Chauhan 2008), similar to the conditions recorded in Lagartos.

During the rainy season, the total biovolume reached its lowest values, the cyanobacteria assemblage was represented by coccoid and filament forms, $\mathrm{NH}_{4}^{+}$concentrations were high $(15-21 \mu \mathrm{M})$ and DIN:SRP ratio was high (40159). Melack (1979), suggests that the rainy season can cause the wash-out of large quantities of phytoplankton from tropical shallow lakes, reducing significantly phytoplankton populations, as was observed in Lagartos. In addition, important growth of Cladophora and Chara (field observations) at the bottom of the lake might compete with a strong uptake of $\mathrm{N}$ and $\mathrm{P}$, with the subsequent decrease of planktonic cyanobacteria.

After analyzing the seasonal variation of cyanobacteria communities in Lagartos, it was not possible to find a plausible explanation about its dynamic. No clear relation between nutrient concentrations and cyanobacteria biovolume values was detected. Paerl (1988) and Oliver \& Ganf (2000) suggested that in freshwater bodies, the most recognized causative agents for cyanobacteria dominance are eutrophication, warm water temperatures, high light intensity and stable weather conditions, very similar to the recorded conditions in Lagartos. Thus, the stability of physical and chemical conditions could favor the dominance of one or two cyanobacteria species in Lagartos. However, there is a range of factors that can be expected to affect cyanobacteria development in this lake. These may include dispersal in this highly mixed habitat, variations in important abiotic parameters (e.g. trace elements, dissolved organic matter), and the impact of selective grazing not measured in this study.

To conclude, water quality data, nitrate enrichment, and trophic state based on biovolume, indicated that Lagartos is a hyposaline, secondarily phosphorus-limited, and eutrophic lake, where the cyanobacteria flora was composed mainly by Chroococcales and Oscillatoriales. Among them, C. pulcherrimus, C. confertum, C. iac, $P$. pachydermaticum and $P$. contorta were recorded for first time in Mexico. Microcystis panniformis and $O$. princeps were the dominant species. The cyanobacteria assemblages in this shallow system could have negative impacts on the ecosystem structure, including blooms of toxic microalgae, like Microcystis, and probably losses of diversity, in agreement with the low richness found during the study period.

\section{ACKNOWLEDGMENTS}

We thank to Viridiana M. Nava and Fermín S. Castillo for their help in the laboratory work. This project was funded through grants from the CONACYT (CONACYT-74164) and CICY A.C. (FQ0009).

\section{RESUMEN}

Los lagos cársticos tropicales en la costa del Caribe mexicano son numerosos. Sin embargo, existe un enorme desconocimiento acerca de sus condiciones limnológicas y de las comunidades de microalgas que se desarrollan en ellos. El objetivo del presente estudio fue estudiar las condiciones limnológicas en las que crecen las poblaciones de cianobacterias planctónicas del lago Lagartos, Quintana Roo, México. Las recolectas se realizaron de forma mensual entre noviembre 2007 y septiembre 2008 . Las especies fueron identificadas y su biovolumen determinado. Se midieron in situ la temperatura del agua, $\mathrm{pH}$, conductividad y salinidad. También, se analizaron las concentraciones de fósforo reactivo soluble (SRP), nitrógeno inorgánico disuelto (DIN) y sílice reactivo soluble (SRSi). Se identificaron 22 especies de cianobacterias. Chroococcus pulcherrimus, Coelosphaerium confertum, Cyanodyction iac, Phormidium pachydermaticum y Planktolyngbya contorta fueron nuevos registros para México. Un exceso de DIN (valor promedio de $42.7 \mu \mathrm{M}$ ) y bajas concentraciones de PRS (valor promedio de $1.0 \mu \mathrm{M}$ ) promovieron la proliferación de cianobacterias. El biovolumen presentó dos picos: el primero en noviembre 2007, dominado por Microcystis panniformis $\left(7.40 \times 10^{8} \mu \mathrm{m}^{3} / \mathrm{mL}\right)$ y el segundo en abril 2008, representado por Oscillatoria princeps $\left(6.55 \times 10^{8} \mu \mathrm{m}^{3} / \mathrm{mL}\right)$. Los datos de calidad del agua, el enriquecimiento por nitratos y el estado trófico basado en 
el biovolumen, indican que Lagartos es un lago hiposalino, eutrófico, con limitación secundaria por fósforo, donde los crecimientos masivos de cianobacterias sin heterocitos fueron recurrentes.

Palabras clave: cianobacteria, proliferación, calidad del agua, nutrientes, eutrófico, Quintana Roo.

\section{REFERENCES}

Alcocer, J., A. Lugo, M.R. Sánchez, E. Escobar \& M. Sánchez. 1999. Bacterioplankton from cenotes and anchialine caves of Quintana Roo, Yucatan Peninsula, Mexico. Rev. Biol. Trop. 1: 19-25.

Almeida, V.P.S., K. Cogo, S.M. Tsai \& D.H. Moon. 2006. Colorimetric test for the monitoring of microcystins in cyanobacterial culture and environmental samples from Southeast Brazil. Braz. J. Microbiol. 37: 192-198.

Anagnostidis, K. \& J. Komárek. 1985. Modern approach to the classification system of cyanophytes 1 . Introduction. Arch. Hydrobiol. 71 (1/2)/Algol. Stud. 38-39: 291-302.

Anagnostidis, K. \& J. Komárek. 1988. Modern approaches to the classification system of cyanophytes. 3. Oscillatoriales. Arch. Hydrobiol. 80 (1/4)/Algol. Stud. 50/53: 327-472.

Beadle, L.C. 1959. Osmotic and ionic regulation in relation to the classification of brackish and inland saline waters. Arch. Oceanogr. Limnol. 11: 143-151.

Carvalho, L.R., C.L. Sant'Anna, M.C.P. Gemelgo \& M.P. Azevedo. 2007. Cyanobacterial occurrence and detection of microcystin by planar chromatography in surface water of Billings and Guarapiranga Reservoirs, SP, Brazil. Rev. Bras. Bot. 30: 141-148.

Casamayor, E.O., M. Llirós, A. Picazo, A. Barberán, C.M. Borrego \& A. Camacho. 2012. Contribution of deep dark fixation processes to overall $\mathrm{CO}_{2}$ incorporation and large vertical changes of microbial populations in stratified karstic lakes. Aquat. Sci. 74: 61-75.

Cerrano, C., F. Azzini, G. Bavestrello, B. Calcinai, M. Pansini, M. Sarti \& D.C. Thung. 2006. Marine lakes of karst islands in Ha Long Bay (Vietnam). Chem. Ecol. 22: 489-500.

Codd, G.A., S.G. Bell, K. Kaya, C.J. Ward, K.A. Beattie \& J.S. Metcalf. 1999. Cyanobacterial toxins, exposure routes and human health. Eur. J. Phycol. 34: 405-415.

Cole, G.A. 1979. Textbook of Limnology. The CV Mosby Company, St. Louis, Missouri. USA.

Comisión Nacional del Agua (CONAGUA). 2002. Determinación de la disponibilidad de agua en el acuífero Península de Yucatán, Estado de Yucatán. Subdirección General Técnica, Gerencia de Aguas Subterráneas. Subgerencia de Evaluación y Modelación
Hidrogeológica. Diario Oficial de la Federación, México.

Danielidis, D.B., M. Spartinou \& A. Economou-Amilli. 1996. Limnological survey of Lake Amavrakia, western Greece. Hydrobiologia 318: 207-218.

Florea, L.J. \& H.L. Vacher. 2006. Springflow hydrographs: Eogenetic vs. telogenetic karst. Ground Water 44: 352-361.

Galat, D.L., E.L. Lider, S. Vigg \& S.R. Robertson. 1981. Limnology of a large, deep, North American terminal lake, Pyramid Lake, Nevada, U.S.A. Hydrobiologia 82: 281-317.

Grasshoff, K., K. Kremling \& M. Ehrhardt. 1983. Methods of seawater analysis. Chemie Weinheim, New York, USA.

Hutchinson, G.E. 1957. A treatise on Limnology. Vol 1. Wiley, New York, USA.

Jensen, J.P., E. Jeppesen, K. Olrik \& P. Kristensen. 1994. Impact of nutrients and physical factors on the shift from cyanobacterial to chlorophyte dominance in shallow Danish lakes. Can. J. Fish. Aquat. Sci. 51: 1692-1699.

Komárek, J. \& K. Anagnostidis. 1998. Cyanoprokaryota I. In H. Ettl, G. Gärtner, H. Heynig \& D. Mollenhauer (eds.). Süßwasserflora von Mitteleuropa 19/1. Gustav Fischer, Jena, Stuttgart, Germany.

Komárek, J. \& K. Anagnostidis. 1999. Cyanoprokaryota I. Teil: Chroococcales. In H. Ettl, G. Gärtner, H. Heynig \& D. Mollenhauer (eds.). Süßwasserflora von Mitteleuropa. Gustav Fischer, Jena, Stuttgart, Germany.

Lopez, N., V. Spizzico \& M. Parise. 2009. Geomorphological, pedological, and hydrological characteristics of karst lakes at Conversano (Apulia, Southern Italy) as a basis for environmental protection. Environ. Geol. 58: 327-337.

López-Adrian, S. \& J.A. Herrera-Silveira. 1994. Plankton composition in a cenote, Yucatan, Mexico. Verch. Int. Verein. Limnol. 25: 1402-1405.

Lu, K., C. Jin, S. Dong, B. Gu \& S.H. Bowen. 2006. Feeding and control of blue-green algal blooms by tilapia (Oreochromis niloticus). Hydrobiologia 568: 111-120.

Mylroie, J.E. \& J.L. Carew. 1995. Karst development on carbonate islands, Chapter 3, p. 55-76. In D.A. Budd, P.M. Harris \& A. Saller (eds.). Unconformities and porosity in carbonate strata: American Association of Petroleum Geologists Memoir 63.

McComb, A.J. \& J.A. Davis. 1993. Eutrophic waters of Southwestern Australia. Fert. Res. 36: 105-11.

McCormick, P.V., R.B.E.I. Shuford, J.G. Backus \& W.C. Kennedy. 1998. Spatial and seasonal patterns of periphyton biomass and productivity in the northern 
Everglades, Florida, U.S.A. Hydrobiologia 362: 185-208.

Melack, J.M. 1979. Temporal variability of phytoplankton in tropical lakes. Oecol. (Berl.) 44: 1-7.

Moss, B. 1990. Engineering and biological approaches to the restoration from eutrophication of shallow lakes in which aquatic plant communities are important components. Hydrobiologia 200/201: 367-378.

Mutchler, T., K.H. Dunton, A. Townsend-Small, S. Fredriksen \& M.K. Rasser. 2007. Isotopic and elemental indicators of nutrient sources and status of coastal habitats in the Caribbean Sea, Yucatan Peninsula, Mexico. Estuar. Coast. Mar. Sci. 74: 449-457.

Oliver, R.L. \& G.G. Ganf. 2000. Freshwater Blooms, p. 149-194. In B.A. Whitton \& M. Potts (eds.). The Ecology of Cyanobacteria: Their Diversity in Time and Space. Kluwer Academic, Dordrecht, Netherlands.

Paerl, H.W. 1988. Nuisance phytoplankton blooms in coastal, estuarine, and inland waters. Limnol. Oceanogr. 33: 823-847.

Reddell, J.R. 1981. A review of the cavernicole, fauna of Mexico, Guatemala, and Belize. Texas Memorial Museum, The University of Texas at Austin. Bulletin 27: 1-327.

Reynolds, C.S. 1984. The Ecology of Freshwater phytoplankton. Cambridge University, Great Britain.

Reynolds, C., V. Huszar, C. Kruk, L. Naselli-Flores \& S. Melo. 2002. Towards a functional classification of the freshwater phytoplankton. J. Plankton Res. 24: 417-428.

Rott, E. 1981. Some results from phytoplankton counting intercalibrations. Schweis. Z. Hydrol. 43: 35-62.

Sánchez, M., J. Alcocer, E. Escobar \& A. Lugo. 2002. Phytoplankton of cenotes and anchialine caves along a distance gradient from Northeastern of Quintana Roo, Yucatan Peninsula. Hydrobiologia 467: 79-89.
Scheffer, M. 1998. Ecology of Shallow Lakes. Chapman \& Hall, London, United Kingdom.

Schmitter-Soto, J.J., F.A. Comín, E. Escobar-Briones, J. Herrera-Silveira, J. Alcocer, E. Suárez-Morales, M. Elías-Gutiérrez, V. Días-Arce, L.E. Marín \& B. Steinich. 2002. Hydrogeochimical and biological characteristics of cenotes in the Yucatan Peninsula (SE Mexico). Hydrobiologia 467: 215-228.

Servicio Meteorológico Nacional (SMN). 2010. Temperatura y precipitación, Estación Meteorológica Automática (EMA) de Sian ka'an.

Smith, V.H. 2003. Eutrophication of freshwater and Coastal Marine Ecosystems. Environ. Sci. \& Pollut. Res. 10: 126-139.

Tiwari, A. \& S.V.S. Chauhan. 2008. Growth and periodicity of cyanobacterial bloom in a polluted pond of Agra city. J. Environ. Biol. 29: 859-862.

Torres-Talamante, O., J. Alcocer, P.A. Beddows, E. Escobar-Briones \& A. Lugo. 2011. The key role of the chemolimnion in meromictic cenotes of the Yucatan Peninsula, Mexico. Hydrobiologia 677: 107-127.

Utermöhl, H. 1958. Zur Vervollkommnung der quantitativen Phytoplankton-Methodik. Mitt. Int. Ver. Limnol. 9: $1-38$.

Vasconcelos, V., A. Martins, M. Vale, A. Antunes, J. Azevedo, M. Welker, O. Lopez \& G. Montejano. 2010. First report on the occurrence of microcystins in planktonic cyanobacteria from Central Mexico. Toxicon 56: 425-431.

Willén, E. 1976. A simplified method of phytoplankton counting. Br. Phycol J. 11: 265-278.

Xie, L.Q., P. Xie \& H.J. Tang. 2003. Enhancement of dissolved phosphorus release from sediment to lake water by Microcystis blooms - an enclosure experiment in a hypereutrophic, subtropical Chinese lake. Environ. Pollut. 112: 391-399. 
